\title{
Climate change impact on agricultural crops and adaptation options in Romania
}

\author{
Vasile C uculeanu ${ }^{1, *}$, Adriana M arica ${ }^{1}$, Catalin Simota ${ }^{2}$ \\ ${ }^{1}$ National Institute of Meteorology and Hydrology, Sos. Bucuresti-Ploiesti 97, RO-71552 Bucharest, Romania \\ ${ }^{2}$ Research Institute for Soil Science and Agrochemistry, Bdul M arasti 61, R0-71331 Bucharest, Romania
}

\begin{abstract}
The aim of this paper is to assess the potential effects of climate change on development, grain yield, and water balance for the main agricultural crops at 5 typical sites located in one of the most vulnerable zones of Romania. In addition, the paper evaluates possible adaptation measures of crop management to future climate changes. The vulnerability assessments focused on winter wheat and maize crops due to the particular importance of these crops in the cultivated areas and the difference in the genetic type of these crops reflected in their distinct physiological responses to $\mathrm{CO}_{2}$ concentration level (winter wheat is a $\mathrm{C}_{3}$ crop, while maize is a $\mathrm{C}_{4}$ crop). Outputs from 2 equilibrium $2 \times \mathrm{CO}_{2}$ general circulation models were used to develop climate change scenarios. CERES simulation models, linked with a seasonal analysis program included in the dedicated software DSSAT v3.0, were run for $30 \mathrm{yr}$ with baseline climate and climate change scenarios. The results of crop simulations under climate change scenarios indicated that winter wheat benefits from the interaction of double $\mathrm{CO}_{2}$ concentrations and higher temperatures, while irrigated maize in southern Romania shows negative responses to climate change. The adverse impact of climate change on the maize crop can be lessened by using a longer maturing hybrid, sowing in the last week of A pril, applying a plant density of 5 plants $\mathrm{m}^{-2}$, and increasing fertilization levels.
\end{abstract}

KEY WORDS: Romania - Winter wheat - Maize - Baseline - GCM outputs · Carbon dioxide · M odels . Adaptation option

\section{INTRODUCTION}

According to the present state of climate science, the increase in greenhouse gas concentrations will result in changes of the climate parameters; particularly, an increase of the global temperature and changes in precipitation are expected. These changes in climate, which are likely to occur during future decades, may have significant consequences (positive or negative) on the development, growth, and yields of crops in Romania, including winter wheat and maize.

There are several reasons for choosing these 2 crops in the vulnerability assessment. Winter wheat and maize are strategic crops in the cultivated areas in southern Romania and represent different agronomic systems: winter wheat is mainly rainfed, and maize is

*E-mail: cuculeanu@meteo.inmh.ro both a rainfed (in few areas) and an irrigated crop (especially in the regions with a warmer and dry climate). The maize crop is sensitive to water availability, especially in the flower initiation/tasseling and silking/grain-filling phases. Winter wheat is a less waterconsumptive crop, but is sensitive to water stress in the anthesis phase. In addition, winter wheat and maize are different plants from the genetic point of view, so their response to doubled atmospheric $\mathrm{CO}_{2}$ is different.

The present paper deals with the effects of climate change on winter wheat and maize development, grain yield, and the main components of water balance using the CERES crop simulation models in conjunction with climate change scenarios derived from equilibrium general circulation models (GCMs). The results of the vulnerability assessment were used to evaluate shifts in agricultural practices that could reduce the potential negative effects of climate change. Different potential adaptation measures were 
analyzed by alternative simulations of agricultural management systems, such as changes in crop variety, sowing date, crop density, as well as changes in the level of fertilization, and application of irrigation.

\section{METHODOLOGY}

2.1. C rop models and management variables. To investigate physiological responses of the winter wheat and maize crop to changes in climate, the CERES simulation crop models were used. The CERES-wheat (Godwin et al. 1989) and CERES-maize (Ritchie et al. 1989) crop-climate models that are included in the Decision Support System for Agrotechnology Transfer (DSSAT) v3.0 program (Tsuji et al. 1994) were calibrated and validated with data obtained from field experiments conducted in the 5 agrometeorological stations of the National Institute of Meteorology and Hydrology, Bucharest, Romania. The models were run for $30 \mathrm{yr}$ with baseline climate and climate change scenarios.

The 2 models have been modified by US Country Studies M anagement Team (1994) to simulate changes in dry matter production and in water balance as a result higher concentrations of atmospheric $\mathrm{CO}_{2}$. In this study, the atmospheric $\mathrm{CO}_{2}$ concentration was set to $330 \mathrm{ppm}$ for the baseline climate, and to $660 \mathrm{ppm}$ for the 2 equilibrium GCM scenarios.

To evaluate alterations in the agricultural practices that would reduce any adverse consequences of the climate change, different adaptive responses were calculated with the CERES-maize model. The simulation output files from running the model for a $30 \mathrm{yr}$ time series period and for different adaptation options were analyzed and compared by using the seasonal analysis program that is also included in DSSAT v3.0. Both biophysical and economic analyses were used to obtain information on potential adaptations to future climate change.

For winter wheat, the data specifying crop growth and phenological development were set for Fundulea4 , one of the most commonly grown winter wheat varieties in southern Romania. Simulations were done for all sites and individual GCM scenarios. The agrotechnology was assumed constant for all simulations: the mean sowing date (Day 274-287, depending on the agroclimatic zone), mean crop density ( 500 plants $\mathrm{m}^{-2}$ ), medium nitrogen supply $\left(60 \mathrm{~kg} \mathrm{ha}^{-1}\right)$, and no irrigation applied.

For maize, the management variables used as input data in the simulation model were held constant for all sites: the mean sowing date was 20 April, crop density 6.0 plants $\mathrm{m}^{-2}$, automatic fertilization $(50 \%$ stress $\mathrm{N})$, and a longer maturing cultivar (F-420). The genetic coefficients defining the phenological development and crop growth were calibrated for the most widely used hybrids in Romania. The water demand at all sites was calculated assuming the following: 100\% efficiency of the automatic irrigation system; $1 \mathrm{~m}$ irrigation management depth; and automatic irrigation when available water was $50 \%$ of soil water capacity. These crop management variables correspond to a medium agrotechnology level specific to Romania.

2.2. Climate change scenarios. Output from 2 individual equilibrium equivalent $2 \times \mathrm{CO}_{2}$ GCMs, the Canadian Climate Centre model (CCCM) and Goddard Institute for Space Studies (GISS) model, were used to create climate change scenarios for the purposes of the present paper. The grid point monthly mean temperature, precipitation amount, and solar radiation derived from GCM simulations are available

Table 1. Adjustment statistics for the difference between $2 \times \mathrm{CO}_{2}$ and current $1 \times \mathrm{CO}_{2}$ generated by the CCCM and GISS GCM S for 2 sites: Craiova and Calarasi in the southern region of Romania

\begin{tabular}{|c|c|c|c|c|c|c|c|c|c|c|c|c|c|c|}
\hline Model & Parameter & Jan & Feb & Mar & Apr & May & Jun & Jul & Aug & Sep & Oct & Nov & Dec & Annual \\
\hline \multicolumn{15}{|l|}{ Craiova } \\
\hline \multirow[t]{3}{*}{$\mathrm{CCCM}$} & Temperature $\left({ }^{\circ} \mathrm{C}\right)$ & 3.8 & 3.4 & 4.1 & 3.2 & 3.5 & 4.8 & 6.0 & 5.2 & 4.4 & 3.5 & 3.5 & 3.1 & 4.0 \\
\hline & Precipitation ratio & 1.04 & 0.87 & 1.02 & 0.88 & 0.88 & 0.69 & 0.92 & 0.91 & 0.77 & 1.15 & 1.11 & 1.15 & - \\
\hline & Radiation ratio & 0.98 & 1.03 & 1.00 & 1.02 & 1.04 & 1.05 & 1.02 & 1.00 & 1.03 & 0.98 & 0.96 & 0.97 & - \\
\hline \multirow[t]{3}{*}{ GISS } & Temperature $\left({ }^{\circ} \mathrm{C}\right)$ & 4.3 & 5.0 & 4.1 & 5.7 & 4.2 & 2.7 & 2.7 & 3.5 & 4.7 & 3.7 & 5.1 & 3.6 & 4.1 \\
\hline & Precipitation ratio & 1.18 & 0.99 & 1.23 & 1.14 & 1.15 & 1.05 & 1.24 & 1.04 & 0.61 & 1.44 & 1.22 & 1.09 & - \\
\hline & Radiation ratio & 0.99 & 0.99 & 0.98 & 1.00 & 1.01 & 0.98 & 0.98 & 1.01 & 1.06 & 0.98 & 1.08 & 1.02 & - \\
\hline \multicolumn{15}{|l|}{ Calorasi } \\
\hline \multirow[t]{3}{*}{ CCCM } & Temperature $\left({ }^{\circ} \mathrm{C}\right)$ & 4.0 & 3.5 & 3.9 & 3.5 & 3.7 & 4.5 & 5.1 & 4.6 & 3.9 & 3.6 & 3.4 & 3.4 & 3.9 \\
\hline & Precipitation ratio & 1.11 & 0.83 & 0.87 & 0.98 & 0.92 & 0.82 & 1.10 & 1.00 & 0.66 & 1.23 & 1.12 & 1.17 & - \\
\hline & Radiation ratio & 0.98 & 1.03 & 1.01 & 1.00 & 1.01 & 1.05 & 1.01 & 1.00 & 1.03 & 0.99 & 0.97 & 0.97 & - \\
\hline \multirow[t]{3}{*}{ GISS } & Temperature $\left({ }^{\circ} \mathrm{C}\right)$ & 4.7 & 5.1 & 4.3 & 5.2 & 4.8 & 3.2 & 3.2 & 4.0 & 4.8 & 3.7 & 5.5 & 4.3 & 4.4 \\
\hline & Precipitation ratio & 1.08 & 0.96 & 1.52 & 0.77 & 1.16 & 1.12 & 0.87 & 0.68 & 0.53 & 1.81 & 0.83 & 1.11 & - \\
\hline & Radiation ratio & 0.95 & 1.00 & 1.01 & 0.98 & 1.00 & 0.98 & 0.98 & 1.03 & 1.06 & 0.98 & 1.16 & 1.07 & - \\
\hline
\end{tabular}


Table 2. Sites in the southern region of Romania used for climate change impact assessment and covering the different agro-pedo-climatic conditions

\begin{tabular}{|lcccrc|}
\hline No. & Site & $\begin{array}{c}\text { Latitude } \\
\left({ }^{\circ} \mathrm{N}\right)\end{array}$ & $\begin{array}{c}\text { Longitude } \\
\left({ }^{\circ} \mathrm{E}\right)\end{array}$ & $\begin{array}{c}\text { Elevation } \\
(\mathrm{m})\end{array}$ & Soil type \\
\hline 1 & Alexandria & 43.59 & 25.21 & 76 & Cambic chernozem \\
2 & Calarasi & 44.12 & 27.21 & 19 & Cambic chernozem \\
3 & Craiova & 44.19 & 23.52 & 192 & Brown reddish \\
4 & Grivita & 44.45 & 27.18 & 50 & Cambic chernozem \\
5 & Targoviste & 44.56 & 25.26 & 297 & Brown reddish \\
\hline
\end{tabular}

from the National Center for Atmospheric Research through the US Country Studies Program (Benioff et al. 1996).

The GCM outputs $\left(1 \times \mathrm{CO}_{2}\right.$ and $\left.2 \times \mathrm{CO}_{2}\right)$ were interpolated for the sites where the climate change impact was assessed. The climate change under $2 \times \mathrm{CO}_{2}$ concentration conditions is estimated as the difference (for temperature) and ratio (for precipitation and solar radiation) between $2 \times \mathrm{CO}_{2}$ and current $1 \times \mathrm{CO}_{2} \mathrm{GCM}$ s. As an example, Table 1 presents the respective values for 2 locations: Craiova and Calarasi.

According to the climate scenarios for the southern region of Romania, the annual temperature would rise by 3.9 to $4.4^{\circ} \mathrm{C}$ and monthly variations of precipitation would range from -47 to $+81 \%$. Generally, precipitation would increase during the autumn and winter and decrease during the summer, depending on the scenarios, sites, and crop seasons. The CCCM scenario provides a higher temperature increase and a more pronounced decrease in the amount of precipitation.

2.3. Climatic data. The SIM METEO weather generator (Geng et al. 1988) was used to create the daily baseline climate data sequences for a $30 \mathrm{yr}$ period (1961 to 1990). Weather data records with a $1 \mathrm{~d}$ time step were generated for minimum, maximum, and mean temperature, precipitation, and solar radiation.

2.4. Simulations. The key steps in the simulation were: (1) Running the crop models with the baseline and climate change scenarios, with the simulation of the direct effects of $\mathrm{CO}_{2}$ on crop development, grain yield, and water balance. (2) Comparing the crop model results from climate change simulations with baseline climate; quantifying the changes in winter wheat and maize yields, changes in growing period length, growing season precipitation and growing season evapotranspiration. (3) Evaluating different agricultural measures that would reduce any adverse consequences to climate change, and selecting the most efficient adaptation measures.

2.5. Selected sites. To perform the present study, 5 representative areas situated in the main agricultural production zone of Romania were selected. These areas are located in the southern part of Romania and cover the different agro-pedo-climatic conditions (Table 2). Depending on the thermic and water resources $(30 \mathrm{yr}$ averages of monthly means of air temperature and precipitation from the growth period of the wheat and maize crops), these 5 locations are characterized by a warmer and moderate dry climate, with a large variability in monthly precipitation amounts and their distribution. An $8.9^{\circ} \mathrm{C}$ average air temperature and $467 \mathrm{~mm}$ of precipitation were calculated for the winter wheat season (October to J uly), and $17.3^{\circ} \mathrm{C}$ and $367 \mathrm{~mm}$ for the maize season (A pril to October). The low precipitation associated with high temperature, especially in the summer months, represents the major factor restricting growth for crops such as maize.

The difference in precipitation amounts and their distribution between the sites leads to different crop management practices: from low-input management systems (minimum amount of the fertilizer application, no irrigation, very simple rotation-with the main crops being winter wheat and maize) to management systems similar to those used in the high-input agriculture of developed countries (optimum fertilizer application, irrigation or complex dry-farming technology, crop rotations suitable for local soil and climate conditions, and so forth).

\section{LIMITATIONS}

A number of yield-limiting factors are not considered in simulations, including phosphorus limitation, negative effects of weed competition, diseases and insect pests, and incidence of catastrophic weather events. In addition, winter wheat varieties, maize hybrids, and crop management are not adapted to future climatic conditions but are held constant as for the baseline conditions.

A full understanding of the possible responses of the crop-environment system to the predicted climate change for Romania can only be gained through consideration of crop-climate interactions at the site, and at regional and national levels. The disadvantages of the site-specific modeling scale used in the present study are caused by a lack of information on the spatial patterns of change.

\section{RESULTS AND DISCUSSION}

The output from the CERES simulation models were used for the vulnerability assessment on winter wheat 
and maize crops. The effects of climate change scenarios on crop yield formation and water balance elements were estimated considering the $30 \mathrm{yr}$ means of the following simulated variables: grain yield ( $\mathrm{t} \mathrm{ha}^{-1}$ of dry matter, or dm), season length (d), amount of the precipitation $(\mathrm{mm})$, and evapotranspiration $(\mathrm{mm})$ in the winter wheat and maize growth period.

\subsection{Winter wheat}

(a) Winter wheat grain yield

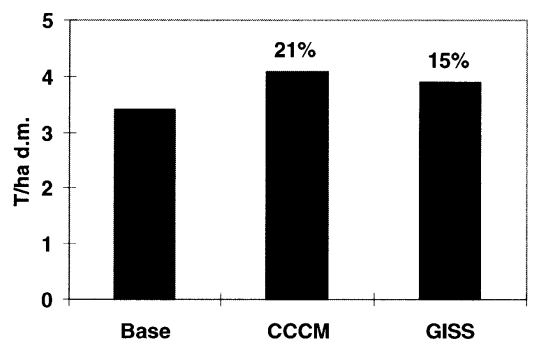

(b) Maize grain yield

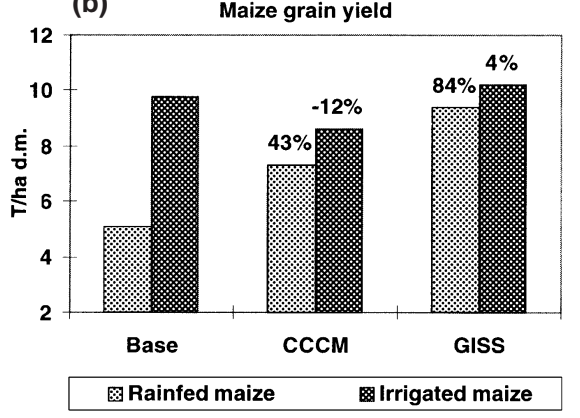

Fig. 1. Changes in grain yield of (a) rainfed winter wheat and (b) rainfed and irrigated maize under $2 \times \mathrm{CO}_{2}$ scenarios (average of the 5 sites) in the southern region of Romania

Table 3. CERES-wheat site-level results by climate change scenarios (with $\mathrm{CO}_{2}$ effect on rainfed winter wheat) for 5 sites in the southern region of Romania. GY: grain yield, SL: season length, PRC: growing season precipitation, ET: growing season evapotranspiration, WUE: water use efficiency (GY/ET).

Change from baseline is shown as a percentage

\begin{tabular}{|c|c|c|c|c|c|c|}
\hline Site & Scenario & $\begin{array}{c}\mathrm{GY} \\
\left(\mathrm{t} \mathrm{ha}^{-1}\right)\end{array}$ & $\begin{array}{l}\mathrm{SL} \\
\text { (d) }\end{array}$ & $\begin{array}{l}\text { PRC } \\
(\mathrm{mm})\end{array}$ & $\begin{array}{c}\text { ET } \\
(\mathrm{mm})\end{array}$ & $\begin{array}{l}\text { WUE } \\
\left(\mathrm{kg} \mathrm{m}^{-3}\right)\end{array}$ \\
\hline Craiova & $\begin{array}{l}\text { Baseline } \\
\text { C C C M } \\
\text { GISS }\end{array}$ & $\begin{array}{r}3.4 \\
12 \% \\
3 \%\end{array}$ & $\begin{array}{l}273 \\
-19 \\
-24\end{array}$ & $\begin{array}{r}412 \\
-7 \% \\
3 \%\end{array}$ & $\begin{array}{r}444 \\
-16 \% \\
-15 \%\end{array}$ & $\begin{array}{c}0.76 \\
33 \% \\
21 \%\end{array}$ \\
\hline Grivita & $\begin{array}{l}\text { Baseline } \\
\text { C C C M } \\
\text { GISS }\end{array}$ & $\begin{array}{r}3.3 \\
21 \% \\
15 \%\end{array}$ & $\begin{array}{l}266 \\
-20 \\
-25\end{array}$ & $\begin{array}{r}347 \\
-11 \% \\
-2 \%\end{array}$ & $\begin{array}{r}445 \\
-14 \% \\
-12 \%\end{array}$ & $\begin{array}{c}0.74 \\
40 \% \\
31 \%\end{array}$ \\
\hline Calarasi & $\begin{array}{l}\text { Baseline } \\
\text { C C C M } \\
\text { GISS }\end{array}$ & $\begin{array}{r}3.2 \\
34 \% \\
25 \%\end{array}$ & $\begin{array}{l}259 \\
-19 \\
-23\end{array}$ & $\begin{array}{r}362 \\
-11 \% \\
1 \%\end{array}$ & $\begin{array}{r}436 \\
-15 \% \\
-12 \%\end{array}$ & $\begin{array}{c}0.73 \\
59 \% \\
42 \%\end{array}$ \\
\hline Alexandria & $\begin{array}{l}\text { Baseline } \\
\text { C C C M } \\
\text { GISS }\end{array}$ & $\begin{array}{r}3.0 \\
33 \% \\
30 \%\end{array}$ & $\begin{array}{l}253 \\
-19 \\
-24\end{array}$ & $\begin{array}{r}370 \\
-15 \% \\
1 \%\end{array}$ & $\begin{array}{r}438 \\
-15 \% \\
-11 \%\end{array}$ & $\begin{array}{c}0.68 \\
57 \% \\
47 \%\end{array}$ \\
\hline Targoviste & $\begin{array}{l}\text { Baseline } \\
\text { CCCM } \\
\text { GISS }\end{array}$ & $\begin{array}{c}4.1 \\
\mathbf{5 \%} \\
\mathbf{2} \%\end{array}$ & $\begin{array}{l}274 \\
-22 \\
-27\end{array}$ & $\begin{array}{r}509 \\
-19 \% \\
-13 \%\end{array}$ & $\begin{array}{r}499 \\
-19 \% \\
-20 \%\end{array}$ & $\begin{array}{c}0.82 \\
29 \% \\
28 \%\end{array}$ \\
\hline
\end{tabular}

Table 3 shows the output of the CERES-wheat sitelevel simulation model and the changes in winter wheat crop variables with climate change scenarios. Changes in crop production and evapotranspiration (the average of the 5 sites) are shown in Figs. 1a \& 2a.

The growing season length of winter wheat for present climate conditions is between 253 and $274 \mathrm{~d}$. Simulated results for the GCM scenarios show that maturity dates occur earlier and the growing season becomes significantly shorter at all sites. The fastest crop development occurs in the case of the GISS scenario (with the growing period from sowing to maturity shorter by 23 to $27 \mathrm{~d}$ on average, in comparison to the baseline), while under the CCCM scenario, maturity is reached 19 to $22 \mathrm{~d}$ earlier than in the case of the baseline.

The CERES-wheat results show the average grain
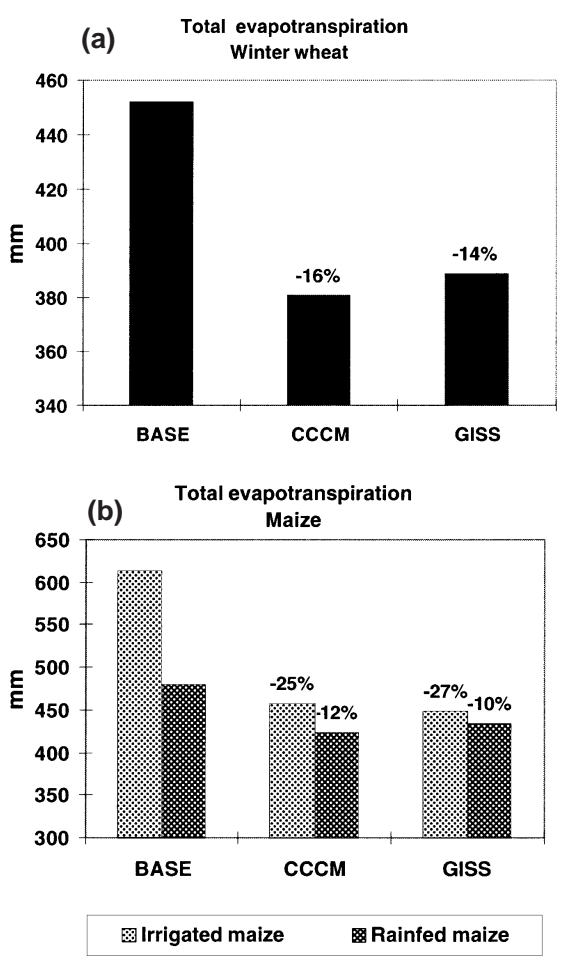

Fig. 2. Changes in growing season evapotranspiration for (a) winter wheat and (b) maize under $2 \times \mathrm{CO}_{2}$ scenarios (average of the 5 sites) in the southern region of Romania yield calculated for the baseline climate (over a $30 \mathrm{yr}$ 
period) varies between $3.0 \mathrm{t} \mathrm{ha}^{-1} \mathrm{dm}$ at Alexandria and $4.1 \mathrm{t} \mathrm{ha}^{-1} \mathrm{dm}$ at the Targoviste site. For the CCCM scenario the average grain yields were higher than for the baseline by 5 to $34 \%$; they were higher by 2 to $30 \%$ in the case of the GISS, scenario. The CCCM scenario predicts the highest increase in grain yield as compared to GISS due to less shortening of the growing season. Yield increases were the largest (33 to $34 \%$ ) at the sites representing the warmer region (Alexandria and Calarasi). The $2 \mathrm{GCM}$ equilibrium scenarios appear to have a positive effect on winter wheat production for all sites analyzed, as a consequence of the photosynthesis process intensification, resulting from doubled atmospheric $\mathrm{CO}_{2}$ concentration. The generally negative effect of the temperature increase that causes a shorter growth period is balanced by the positive effect of doubled $\mathrm{CO}_{2}$ (van de Geijin et al. 1993).

The amount of precipitation during the growth period of the wheat differs according to the local conditions, between 347 and $509 \mathrm{~mm}$, in the baseline climate. For the CCCM scenario, the growing season precipitation decreases by 7 to $19 \%$. For the GISS scenario, precipitation during the growing season slightly increases by 1 to $3 \%$ on average at 3 sites; for the other 2 sites (Grivita and Targoviste), precipitation in the growing season decreases by an average of 2 to $13 \%$. The cumulative water losses by evapotranspiration during the vegetation period decreases, compared with the present level, by an average of 11 to $20 \%$ at all sites in the 2 scenarios, as a result of growing season shortening caused by temperature increase. The winter wheat crop uses the available soil water more efficiently in both climate scenarios; the crop water use efficiency increases significantly, by as much as 47 to $59 \%$, compared with the actual conditions, due mainly to the increased $\mathrm{CO}_{2}$ assimilation rate.

\subsection{Maize}

The maize crop is very sensitive to the technology level, the local conditions of each site, and the severity of climate change scenarios. The CERES-maize model was run for both current and future climate conditions in 2 cases: rainfed and irrigated crops.

\subsubsection{Simulation with direct $\mathrm{CO}_{2}$ effect on rainfed maize}

Table 4 shows the site-level results obtained using the CERES-maize model and changes in rainfed maize with the climate change scenarios. Changes in grain
Table 4. CERES-maize site-level results by climate change scenario (with $\mathrm{CO}_{2}$ effect on rainfed maize) for 5 sites in the southern region of Romania. GY: grain yield, SL: season length, PRC: growing season precipitation, ET: growing season evapotranspiration, WUE: water use efficiency (GY/ET).

\begin{tabular}{|c|c|c|c|c|c|}
\hline Site & 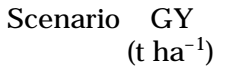 & $\begin{array}{l}\text { SL } \\
\text { (d) }\end{array}$ & $\begin{array}{l}\text { PRC } \\
(\mathrm{mm})\end{array}$ & $\begin{array}{l}\text { ET } \\
(\mathrm{mm})\end{array}$ & $\begin{array}{c}\text { WUE } \\
\left(\mathrm{kg} \mathrm{m}^{-3}\right)\end{array}$ \\
\hline Craiova & $\begin{array}{lr}\text { Baseline } & 4.5 \\
\text { CCCM } & \mathbf{3 8} \% \\
\text { GISS } & \mathbf{1 1 5} \%\end{array}$ & $\begin{array}{r}130 \\
-17 \\
-7\end{array}$ & $\begin{array}{r}368 \\
-12 \% \\
18 \%\end{array}$ & $\begin{array}{r}471 \\
-12 \% \\
-7 \%\end{array}$ & $\begin{array}{r}0.96 \\
55 \% \\
130 \%\end{array}$ \\
\hline Grivita & $\begin{array}{lr}\text { Baseline } & 5.0 \\
\text { CCCM } & \mathbf{7 4 \%} \\
\text { GISS } & \mathbf{1 1 4} \%\end{array}$ & $\begin{array}{r}122 \\
-12 \\
-9\end{array}$ & $\begin{array}{l}340 \\
0 \% \\
4 \%\end{array}$ & $\begin{array}{r}439 \\
-5 \% \\
-6 \%\end{array}$ & $\begin{array}{r}1.14 \\
83 \% \\
126 \%\end{array}$ \\
\hline Calarasi & $\begin{array}{lr}\text { Baseline } & 5.9 \\
\text { CCCM } & \mathbf{3 8} \% \\
\text { GISS } & \mathbf{7 2} \%\end{array}$ & $\begin{array}{l}120 \\
-14 \\
-11\end{array}$ & $\begin{array}{r}325 \\
-8 \% \\
1 \%\end{array}$ & $\begin{array}{r}426 \\
-8 \% \\
-7 \%\end{array}$ & $\begin{array}{l}1.38 \\
51 \% \\
87 \%\end{array}$ \\
\hline Alexandria & $\begin{array}{lr}\text { Baseline } & 2.9 \\
\text { CCCM } & \mathbf{4 4 \%} \\
\text { GISS } & \mathbf{1 1 9} \%\end{array}$ & $\begin{array}{r}121 \\
-14 \\
-6\end{array}$ & $\begin{array}{r}385 \\
-19 \% \\
4 \%\end{array}$ & $\begin{array}{r}480 \\
-13 \% \\
-7 \%\end{array}$ & $\begin{array}{r}0.60 \\
67 \% \\
138 \%\end{array}$ \\
\hline Targoviste & $\begin{array}{lr}\text { Baseline } & 7.2 \\
\text { CCCM } & \mathbf{2 9} \% \\
\text { GISS } & \mathbf{4 4} \%\end{array}$ & $\begin{array}{l}156 \\
-32 \\
-26\end{array}$ & $\begin{array}{r}532 \\
-13 \% \\
-2 \%\end{array}$ & $\begin{array}{r}578 \\
-19 \% \\
-18 \%\end{array}$ & $\begin{array}{c}1.25 \\
58 \% \\
75 \%\end{array}$ \\
\hline
\end{tabular}

yield of the rainfed maize and the total evapotranspiration (the average of the 5 sites) under $2 \times \mathrm{CO}_{2}$ scenarios are shown in Figs. $1 \mathrm{~b} \& 2 \mathrm{~b}$.

The average maize grain yield estimated for the current climate conditions ranges between $2.9 \mathrm{t} \mathrm{ha}^{-1} \mathrm{dm}$ at Alexandria and $7.2 \mathrm{t} \mathrm{ha}^{-1} \mathrm{dm}$ at Targoviste. Under climate change conditions, the grain yield appears to increase considerably for all sites considered under the 2 scenarios. The CCCM scenario resulted in an increase in the grain yield by 29 to $74 \%$, compared with the baseline. For the GISS scenario, the increase ranges from 44 to more than $100 \%$. These data show that for the GISS scenario the $\mathrm{CO}_{2}$ assimilation rate (AMAX) reaches its maximum (potential) value. The data are consistent with the AMAX values obtained in controlled climatic chambers (Goudriaan \& Unsworth 1990).

For rainfed conditions, the growing season length decreases by 12 to $32 \mathrm{~d}$ for CCCM and by 6 to $26 \mathrm{~d}$ for GISS. Compared with the baseline climate, the amount of precipitation during the vegetation period decreases up to $19 \%$ in the CCCM scenario and increases by 1 to $18 \%$ in the GISS scenario (except at the Targoviste site, where it slightly decreases by $2 \%)$. The simulated results show a decrease of the total evapotranspiration during the growth period for all sites and both scenarios (5 to $19 \%$ ). The water use efficiency (ratio of crop yield to total crop evapotranspiration) greatly increases under climate change conditions, particularly in the case of the GISS scenario. 
Table 5. CERES-maize site-level results by climate change scenarios (with $\mathrm{CO}_{2}$ effect on irrigated maize) for 5 sites in the southern region of Romania. GY: grain yield, SL: season length, PRC: growing season precipitation, ET: growing season evapotranspiration, IRR: water used for irrigation, WUE: water use efficiency (GY/ET), IUE: irrigation use efficiency (GY/IRR). Change from baseline is shown as a percentage

\begin{tabular}{|c|c|c|c|c|c|c|c|c|}
\hline Site & Scenario & $\begin{array}{c}\mathrm{GY} \\
\left(\mathrm{t} \mathrm{ha}^{-1}\right)\end{array}$ & $\begin{array}{l}\mathrm{SL} \\
\text { (d) }\end{array}$ & $\begin{array}{l}\text { PRC } \\
(\mathrm{mm})\end{array}$ & $\begin{array}{c}\text { ET } \\
(\mathrm{mm})\end{array}$ & $\begin{array}{l}\text { IRR } \\
(\mathrm{mm})\end{array}$ & $\begin{array}{l}\text { WUE } \\
\left(\mathrm{kg} \mathrm{m}^{-3}\right)\end{array}$ & $\begin{array}{c}\text { IUE } \\
\left(\mathrm{kg} \mathrm{m}^{-3}\right)\end{array}$ \\
\hline Craiova & $\begin{array}{l}\text { Baseline } \\
\text { CCC M } \\
\text { GISS }\end{array}$ & $\begin{array}{r}9.4 \\
-17 \% \\
8 \%\end{array}$ & $\begin{array}{l}155 \\
-37 \\
-32\end{array}$ & $\begin{array}{r}399 \\
-14 \% \\
9 \%\end{array}$ & $\begin{array}{r}586 \\
-22 \% \\
-24 \%\end{array}$ & $\begin{array}{r}138 \\
-46 \% \\
-70 \%\end{array}$ & $\begin{array}{r}1.60 \\
8 \% \\
44 \%\end{array}$ & $\begin{array}{r}6.81 \\
51 \% \\
257 \%\end{array}$ \\
\hline Grivita & $\begin{array}{l}\text { Baseline } \\
\text { CCCM } \\
\text { GISS }\end{array}$ & $\begin{array}{c}10.3 \\
-6 \% \\
12 \%\end{array}$ & $\begin{array}{l}146 \\
-34 \\
-32\end{array}$ & $\begin{array}{r}373 \\
-11 \% \\
-3 \%\end{array}$ & $\begin{array}{r}607 \\
-28 \% \\
-30 \%\end{array}$ & $\begin{array}{r}182 \\
-62 \% \\
-74 \%\end{array}$ & $\begin{array}{l}1.70 \\
30 \% \\
59 \%\end{array}$ & $\begin{array}{r}5.66 \\
142 \% \\
323 \%\end{array}$ \\
\hline Calarasi & $\begin{array}{l}\text { Baseline } \\
\text { CCCM } \\
\text { GISS }\end{array}$ & $\begin{array}{r}10.8 \\
-16 \% \\
-2 \%\end{array}$ & $\begin{array}{l}133 \\
-26 \\
-24\end{array}$ & $\begin{array}{r}330 \\
-9 \% \\
-1 \%\end{array}$ & $\begin{array}{r}563 \\
-25 \% \\
-28 \%\end{array}$ & $\begin{array}{r}172 \\
-55 \% \\
-68 \%\end{array}$ & $\begin{array}{c}1.92 \\
13 \% \\
36 \%\end{array}$ & $\begin{array}{r}6.28 \\
86 \% \\
207 \%\end{array}$ \\
\hline Alexandria & $\begin{array}{l}\text { Baseline } \\
\text { CCCM } \\
\text { GISS }\end{array}$ & $\begin{array}{r}7.8 \\
-14 \% \\
-3 \%\end{array}$ & $\begin{array}{l}149 \\
-33 \\
-28\end{array}$ & $\begin{array}{r}410 \\
-23 \% \\
2 \%\end{array}$ & $\begin{array}{r}649 \\
-22 \% \\
-24 \%\end{array}$ & $\begin{array}{r}191 \\
-33 \% \\
-64 \%\end{array}$ & $\begin{array}{l}1.20 \\
13 \% \\
29 \%\end{array}$ & $\begin{array}{c}4.08 \\
29 \% \\
166 \%\end{array}$ \\
\hline Targoviste & $\begin{array}{l}\text { Baseline } \\
\text { CCC M } \\
\text { GISS }\end{array}$ & $\begin{array}{r}11.0 \\
-14 \% \\
-5 \%\end{array}$ & $\begin{array}{l}180 \\
-56 \\
-50\end{array}$ & $\begin{array}{r}555 \\
-15 \% \\
-6 \%\end{array}$ & $\begin{array}{r}660 \\
-29 \% \\
-28 \%\end{array}$ & $\begin{array}{r}108 \\
-70 \% \\
-80 \%\end{array}$ & $\begin{array}{r}1.67 \\
20 \% \\
32 \%\end{array}$ & $\begin{array}{r}10.1 \\
183 \% \\
367 \%\end{array}$ \\
\hline
\end{tabular}

$9 \%$ for the other 2 sites) under the GISS scenario. The cumulative water losses by evapotranspiration during the vegetation period decreases significantly $(22$ to $30 \%$ ), compared with the baseline climate for all locations and both scenarios, because of the shortening of the growth period. The reduction in the total evapotranspiration of the irrigated maize (the average of the 5 sites) is larger than it is for rainfed maize or winter wheat (Fig. 2). Water use efficiency increases in all cases. In order to maintain the same management practices as in the baseline, the irrigation needs to decrease in both climate change scenarios up to 70 to $80 \%$, while the irrigation use efficiency has a great increase, especially in the case of GISS scenario. These irrigation decreases have to be carefully interpreted in relation to the significant shortening of the maize growing season.

\subsubsection{Simulation with direct $\mathrm{CO}_{2}$ effect on irrigated maize}

Table 5 shows the results of the simulations with $\mathrm{CO}_{2}$ effect on irrigated maize. Figs. $1 b \& 2 b$ show the changes in grain yield and evapotranspiration of the irrigated maize (the average of the 5 sites) under $2 \times$ $\mathrm{CO}_{2}$ scenarios.

The analyses of the simulated results in the case of intensive management systems, in the present climatic conditions, show that the average grain yield is higher by about $5 \mathrm{t} \mathrm{ha}^{-1} \mathrm{dm}$ than in rainfed conditions. The yields are in the range of 7.8 to $11.0 \mathrm{tha}^{-1} \mathrm{dm}$ The average grain yield for irrigated maize decreases by 6 to $17 \%$ for the CCCM scenario at all sites. For the GISS scenario, the yield increases by 8 to $12 \%$ at 2 sites (Craiova and Grivita) or slightly decreases by 2 to $5 \%$ at the other 3 sites.

Yield reduction, especially in the case of CCCM (a hot and dry scenario), occurs due to much shorter grain-filling periods ( 26 to $56 \%$ ), caused by the higher temperatures and the relatively small photosynthetic benefits of $\mathrm{CO}_{2}$ concentration that are associated with $\mathrm{C}_{4}$ plants such as maize (Simota \& Marica 1997).

The amount of precipitation during the growth period of the maize is different, according to the local conditions, between 330 and $555 \mathrm{~mm}$, in the baseline climate. The growing season precipitation decreases by 9 to $23 \%$ on average at all sites under the CCCM scenario and slightly decreases ( 1 to $6 \%$ for 3 sites) or increases ( 2 to

\subsection{Possible adaptive responses}

Results of the vulnerability assessment on winter wheat and maize crops presented above show that maize productivity in the southern part of Romania can be affected by future climate change. To evaluate alterations in agricultural practices that would reduce the potential negative effects of climate change on irrigated maize production, the following adaptation options were analyzed: changes in the crop variety, sowing date, crop density, and fertilization level. The results from CERES-maize simulation models for the medium-input agriculture systems highlight a variation in maize yields among sites. For an easy comparison, the 5 site-level results for the $2 \times \mathrm{CO}_{2}$ scenarios were averaged. Table 6 shows irrigated maize grain yield changes by altered maize hybrids, sowing dates, crop density, and fertilizer levels.

\subsubsection{Cultivar adaptation}

Three maize hybrids (with a low-, medium- and high-temperature sum required for the grain-filling-P5 coefficient) were chosen to examine the possibility of management responses to climate change. The use of a maize cultivar with a high grain-filling duration coefficient $(\mathrm{H} 3)$ resulted in the yield increase in all sites analyzed compared with the hybrids with a low or medium grain-filling duration coefficient $(\mathrm{H} 1$ or $\mathrm{H} 2)$. Yield 
losses were lower $(-8 \%)$, in the case of the CCCM scenario, by using a longer maturing hybrid, than by using the hybrids with a low or medium grain-filling duration coefficient (-12 and $-11 \%)$.

\subsubsection{Change in the sowing date}

For maize crop, the impacts of 5 different planting dates were assessed from March 20 to A pril 30. The predicted grain yields of irrigated maize increased by $0.6 \mathrm{t} \mathrm{ha}^{-1}$ (from 9.0 to $9.6 \mathrm{t} \mathrm{ha}^{-1}$ ) in the CCCM scenario and by $0.7 \mathrm{t} \mathrm{ha}^{-1}$ (from 10.3 to $11 \mathrm{t} \mathrm{ha}^{-1}$ ) in the GISS scenario, with a later sowing date (A pril 30), in comparison with the present dates (April 20). For the CCCM scenario, the grain yields decrease in all cases, but less so for the later sowing dates $(-9 \%)$ than for the earlier ones $(-14 \%)$. The yield losses are reduced in this scenario for the sowing on A pril 30. In the case of GISS scenario, the grain yields showed an increasing trend for all the alternative sowing dates, but this was more evident for the later sowing date $(+5 \%)$. For both current and future climatic scenarios, the later sowing date resulted in an increase in maize yields.

\subsubsection{Change in crop density}

The effects of climate change on maize yields may be diminished also by using a low crop density ( 5 plants $\mathrm{m}^{-2}$ ). This leads to a general increase in mean maize yields by $1.4 \mathrm{t} \mathrm{ha}^{-1}$ for both climate change scenarios (from 7.6 to $9.0 \mathrm{t} \mathrm{ha}^{-1}$ in the CCCM scenario and from 8.9 to $10.3 \mathrm{t} \mathrm{ha}^{-1}$ in the GISS scenario), as compared with those predicted using a higher crop density (8 plants $\mathrm{m}^{-2}$ ).

\subsubsection{Change in fertilizer levels}

To examine the effect of the fertilizer level increases, 3 cases for automatic application of nitrogen were used: a medium variant (N1) in which the nitrogen stress reaches $50 \%$, and 2 other variants in which the stress diminishes up to 20 (N2) and 10\% (N3). The other management variables were maintained constant: automatic irrigation, sowing date of April 30, a longer maturing hybrid, and a crop density of 5 plants $\mathrm{m}^{-2}$.

The progressive increase of the nitrogen amount applied in the vegetation season, from $50-70 \mathrm{~kg} \mathrm{ha}^{-1}$ to $120-160 \mathrm{~kg} \mathrm{ha}^{-1}$ (as the result of the decreased stress), determines the maize yield increase in both actual (from 10.6 to $13.5 \mathrm{t} \mathrm{ha}^{-1}$ ) and future climates (from 9.5
Table 6. Irrigated grain yield changes due to altered maize hybrids, sowing dates, crop density and fertilizer levels (average of the 5 sites) in the southern region of Romania. Weighted and percent changes from baseline yield

\begin{tabular}{|c|c|c|c|c|c|}
\hline \multirow{2}{*}{$\begin{array}{l}\text { Alternative } \\
\text { Hybrid }\end{array}$} & \multirow[t]{2}{*}{$\begin{array}{l}\text { Baseline } \\
\left(\mathrm{t} \mathrm{ha}^{-1}\right)\end{array}$} & \multicolumn{2}{|c|}{$\begin{array}{c}\text { CCCM } \\
\left(\mathrm{t} \mathrm{ha}^{-1}\right) \quad(\%)\end{array}$} & \multicolumn{2}{|c|}{$\begin{array}{c}\text { GISS } \\
\left(\mathrm{t} \mathrm{ha}^{-1}\right)(\%)\end{array}$} \\
\hline & & & & & \\
\hline H1 (Pio 3780) & 8.2 & 7.2 & -12 & 8.6 & 5 \\
\hline H2 (Pio 3382) & 8.8 & 7.8 & -11 & 8.9 & 1 \\
\hline H3 (F 420) & 10.4 & 9.6 & -8 & 11.2 & 8 \\
\hline \multicolumn{6}{|l|}{ Sowing dates } \\
\hline Mar 20 & 8.9 & 7.7 & -13 & 9.1 & +2 \\
\hline Apr 1 & 9.1 & 7.8 & -14 & 9.5 & +4 \\
\hline Apr 10 & 9.6 & 8.4 & -13 & 9.8 & +2 \\
\hline Apr 20 & 10.1 & 9.0 & -11 & 10.3 & +2 \\
\hline Apr 30 & 10.5 & 9.6 & -9 & 11.0 & +5 \\
\hline \multicolumn{6}{|c|}{ Crop density (plants $\mathrm{m}^{-2}$ ) } \\
\hline 8 & 8.5 & 7.6 & -11 & 8.9 & +5 \\
\hline 7 & 8.9 & 7.9 & -11 & 9.3 & +5 \\
\hline 6 & 9.4 & 8.4 & -11 & 9.8 & +4 \\
\hline 5 & 10.1 & 9.0 & -11 & 10.3 & +2 \\
\hline \multicolumn{6}{|c|}{ Fertilizer levels (kg ha-1) } \\
\hline N1: $50-70$ & 10.6 & 9.5 & -10 & 10.7 & +1 \\
\hline N2: $110-120$ & 11.1 & 9.8 & -12 & 11.4 & +4 \\
\hline N3: $120-160$ & 13.5 & 11.0 & -18 & 14.5 & +7 \\
\hline
\end{tabular}

to $11 \mathrm{t} \mathrm{ha}^{-1}$ in the CCCM scenario and from 10.7 to $14.5 \mathrm{t} \mathrm{ha}^{-1}$ in the GISS scenario).

\section{CONCLUSIONS}

Climate change effects on agricultural crops in the southern part of Romania depend on local conditions of each site, the severity of changes in climate, and the direct physiological effects of a double $\mathrm{CO}_{2}$ concentration.

Winter wheat could benefit from the interaction of a double $\mathrm{CO}_{2}$ concentration with higher temperatures, while maize appears to be vulnerable to climate change, especially in the case of a warm and dry scenario (such as CCCM). Wheat yields increased at all sites for the 2 climate change scenarios as a result of large direct effects of doubling $\mathrm{CO}_{2}$ on photosynthesis and water use. The negative effect of the temperature increase that causes a shorter growth period would be counterbalanced by the positive effect of the doubling $\mathrm{CO}_{2}$ concentration.

The impact on maize is different according to the scenario and the management practices used: in the case of rainfed maize, the grain yield increases significantly for both scenarios, while in the case of the irrigated maize the grain yield decreases for the CCCM scenario and increases or slightly decreases depending on the sites for the GISS scenario. Yield decreases are a result of increasing temperatures that shorten the 
season length associated with the water stress during the grain filling.

For both crops, the cumulative evapotranspiration during the growth season generally decreases, as a result of growing season shortening, but with different strengths according to the crop type and management practices. Under the climate change conditions, water is used more efficiently by the 2 crops.

For maize, the economic risk analysis suggests that the dominant strategy use the following adaptation options: the application of irrigation, use of longer maturing hybrids, sowing in the last 10 days of April, use of a plant density of 5 plants $\mathrm{m}^{-2}$, and the increase of nitrogen levels up to $120-160 \mathrm{~kg} \mathrm{ha}^{-1}$.

The assessment of the direct effects of $\mathrm{CO}_{2}$ on crop production remains an important research question. Although many studies have confirmed the beneficial effect of $\mathrm{CO}_{2}$ on the mean responses of crops (especially for $\mathrm{C}_{3}$ crops, including winter wheat), variation in responsiveness between plant species persists.

Development and improvement of the agricultural modeling approaches particularly applicable at the regional scale warrant increased attention.

Acknowledgements. The dedicated software DSSAT v3.0 and the grid point monthly mean temperature, precipitation amount and solar radiation derived from GCM simulations were made available by the US Country Studies Program financed by the United States Environmental Protection Agency. We acknowledge the US Country Study Team for their excellent collaboration.

\section{LITERATURE CITED}

Benioff R, Guill S, Lee J (eds) (1996) Vulnerability and adaptation assessments: an international guidebook. Kluwer Academic Publisher, Dordrecht

Geng S, Auburn J S, Brandsetter E, Li B (1988) A program to simulate meteorological variables: documentation for SIM METEO. Agronomy Progress report No. 204. Dept of Agronomy and Range Science, University of California

Godwin DC, Ritchie JT, Singh U, Hunt L (1989) A user's guide to CERES-Wheat: v2.10. International Fertilizer Development Center, Muscle Shoals, AL

Goudriaan J , Unsworth MH (1990) Implications of increasing carbon dioxide and climate change for agricultural productivity and water resources. In: Kimball BA, Rosenberg NJ, Hartwell AL, Heichel GH, Stuber CW, Kissel DE (eds) Impact of carbon dioxide, trace gasses, and climate change on global agriculture. ASA Spec Publ No. 53. American Society of Agronomy, Crop Science Society of America, Madison, $p$ 111-130

Ritchie J T, Singh U, Godwin DC, Hunt L (1989) A user's guide to CERES-maize: v2.10. International Fertilizer Development Center, M uscle Shoals, AL

Simota C, Marica A (1997) Assessment of the potential effects of climate change on agriculture ecosystem and evaluation adaptation measures. In: Cuculeanu V (ed) Country study on climate change in Romania. Element 2: Vulnerability assessment and adaptation options. Final Report, US Country Studies Program, p 2.1-2.88

Tsuji GI, Uehara G, Balas S (eds) (1994) DSSAT v3.0, Vols 1, 2 and 3. University of Hawaii, Honolulu

US Country Studies M anagement Team (PO-63) (1994) Guidance for vulnerability and adaptation assessment. US Country Studies Program, Washington, DC

van de Geijin SC, Goudriaan J, Berendse F (1993) Climate change; crops and terrestrial ecosystems. CABO-DLO Wageningen 